HD

2796

R43

1912

NMAH

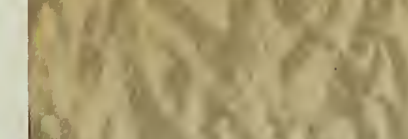

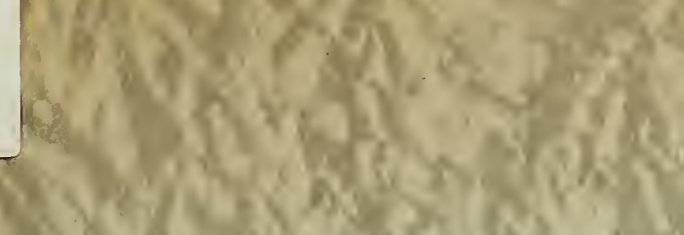

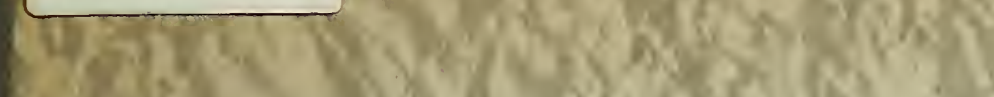
(y)

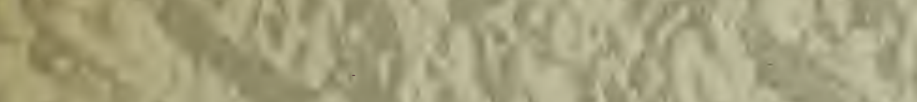

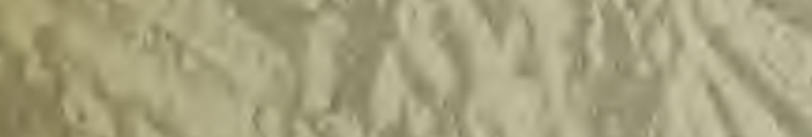

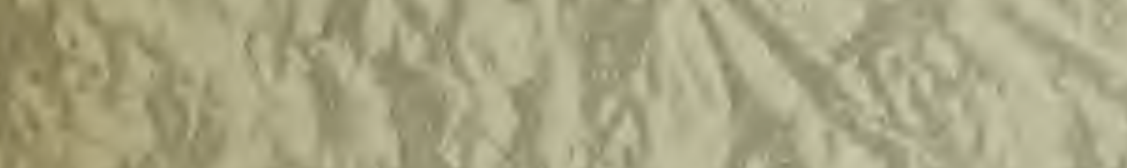
(3)

7.

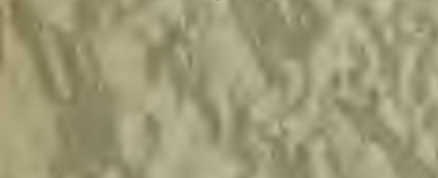

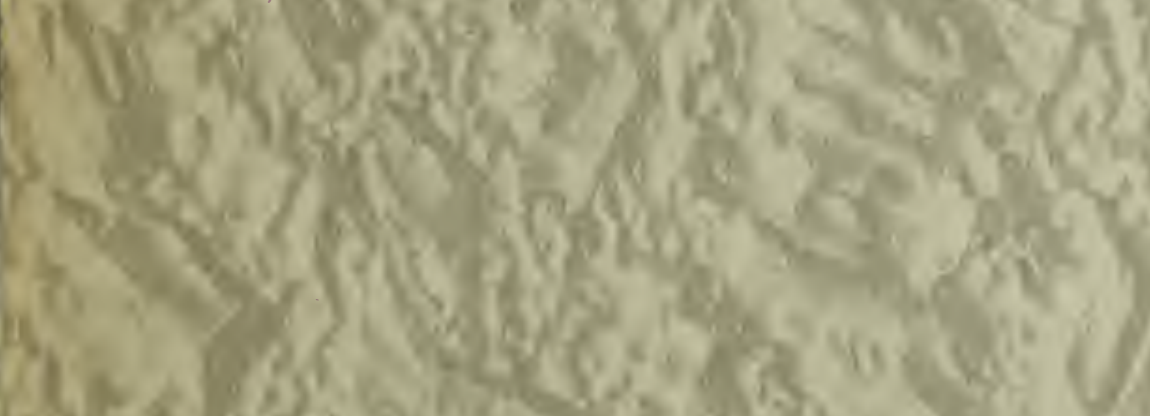

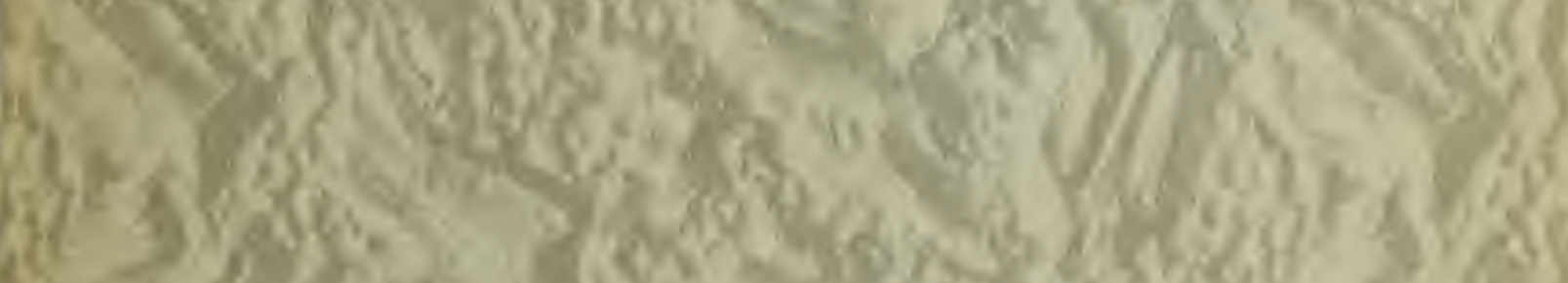

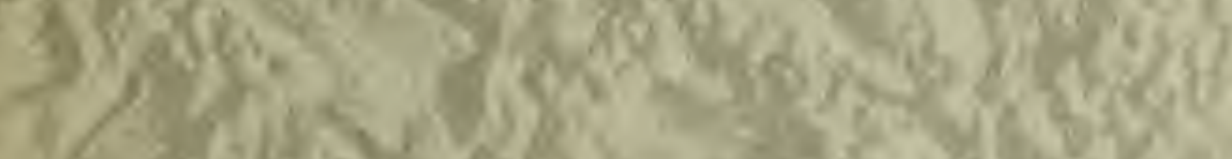

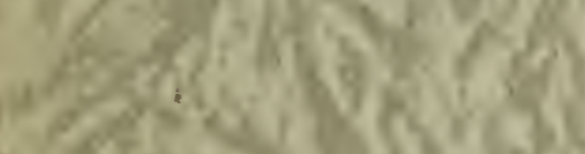

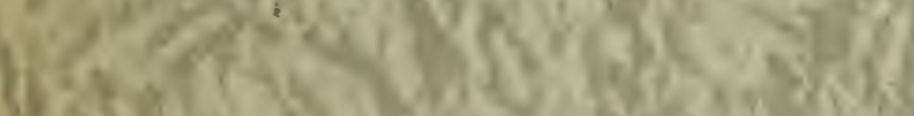

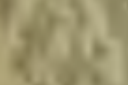

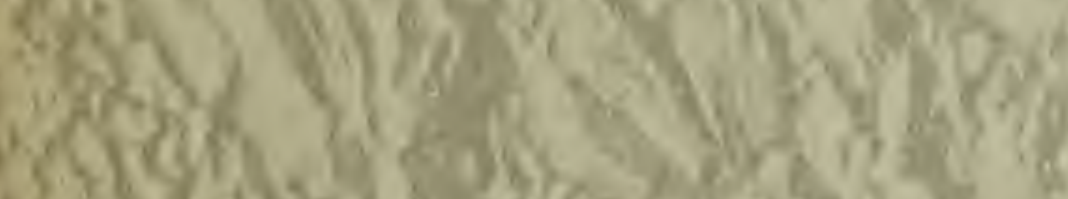

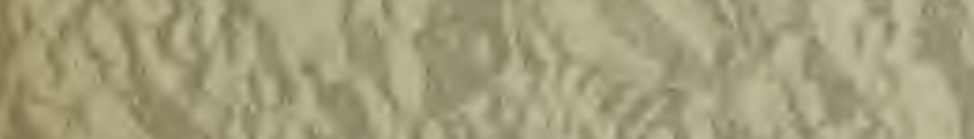

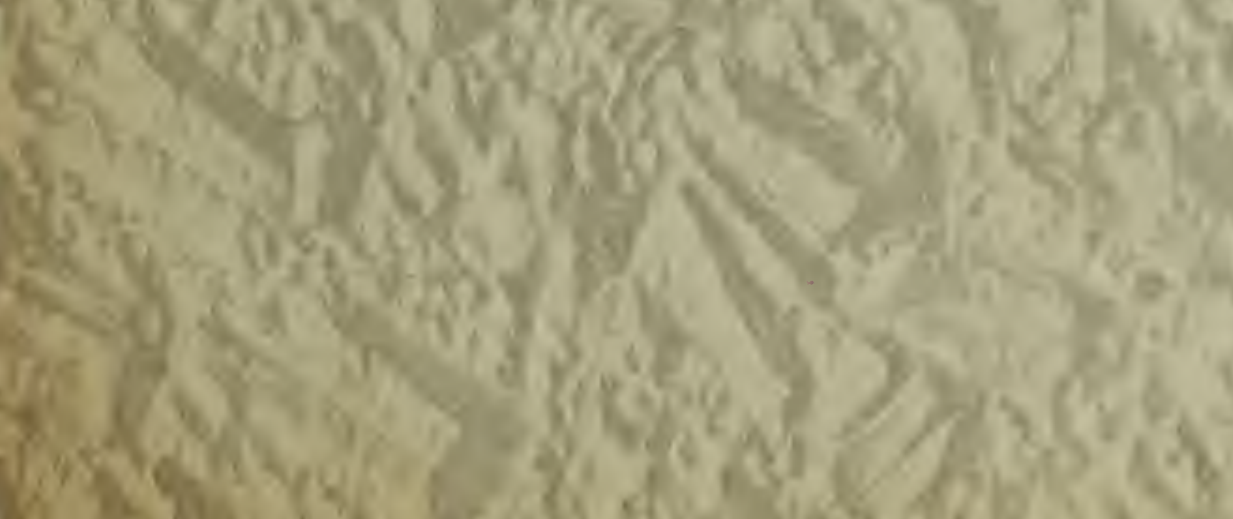






\section{Research Corporation}

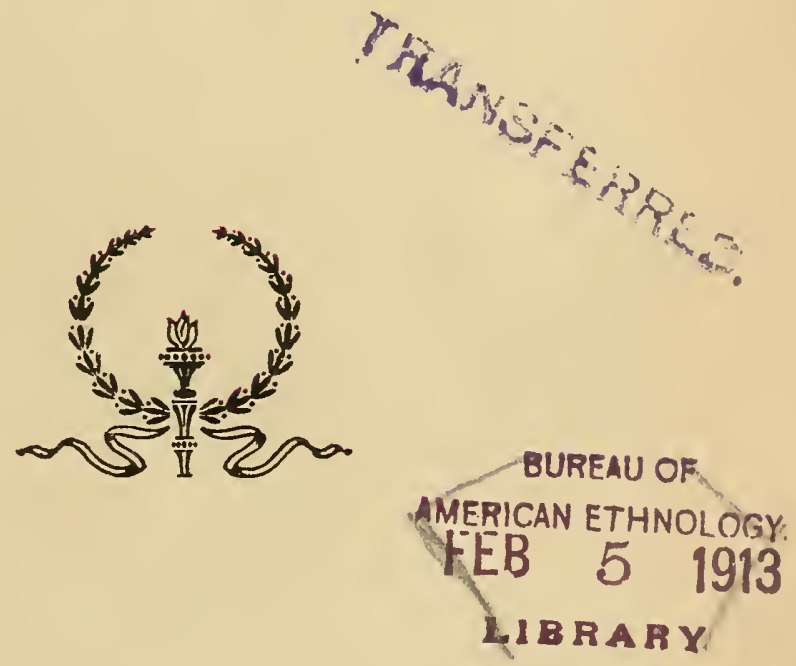

GERTIFICATE OF INCORPORATION, BY-LAWS

AND STOCKHOLDERS' AGREEMENT 


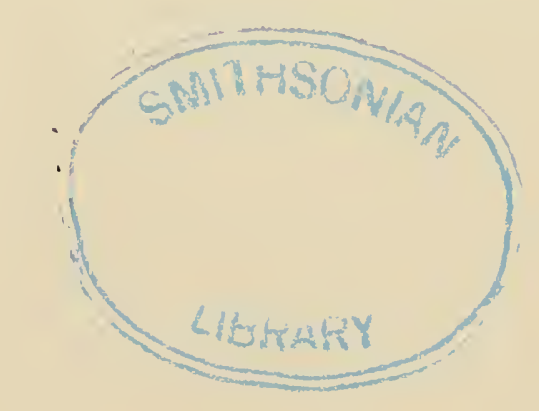




\title{
Research Corporation
}

Office-63 Wall Street

NEW YORK

\section{Officers}

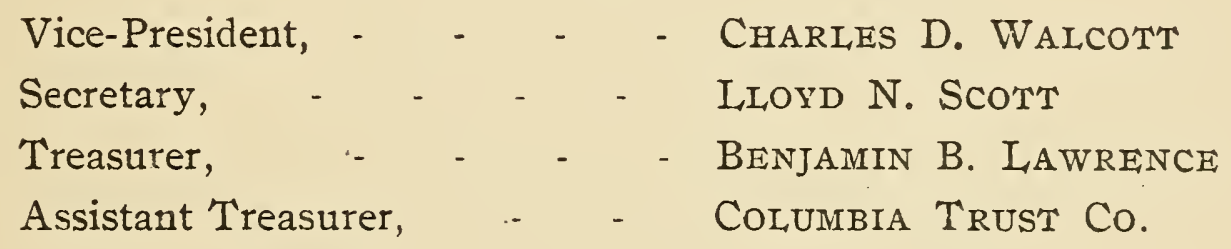

\section{Directors}

TO SERVE UNTIL 1913
T. Coleman du Pont
Charles A. Stone
Arthur D. Littile
Elihu ThOMSON

MARK S. REARDON

TO SERVE UNTIL 1914

\begin{abstract}
Frederick A. Goetze
JoHn B. Pine

Benjamin B. Lawrence

LLOYD N. SCOTT
\end{abstract}

Charles D. Walcott

TO SERVE UNTIL 1915
Thomas C. Meadows
HenNen Jennings
ELON H. HOOKER
CHARLES KIRCHHOFF

JAMES J. STORROW

John B. Pine, Counsel 



\section{CERTIFICATE OF INCORPORATION}

THIS IS TO CERTIFY, that we the undersigned, all being persons of full age and all citizens of the United States and all of whom are residents of the State of New York, desiring to form a stock corporation, for the purpose of aiding and encouraging technical and scientific research as hereinafter more particularly described, pursuant to the provisions of the General Corporation Law, the Business Corporations Law and the Stock Corporation Law of the State of New York, do hereby make, sign, acknowledge and file the following certificate :

FIRST: The name of the proposed corporation shall be

"REShaRch Corporation."

SECOND: The purposes of the proposed corporation are :

(a) To receive by gift and to acquire by purchase or otherwise, inventions, patent rights and letters patent either of the United States or foreign countries, and to hold, manage, use, develop, manufacture, install and operate the same, and to conduct commercial operations under or in connection with the development of such inventions, patent rights and letters patent and to sell, license, or otherwise dispose of the same, and to collect royalties thereon, and to experiment with and test the validity and value thereof, and to render the same more available and effective in the useful arts and manufactures and for scientific purposes and otherwise.

(b) To provide means for the advancement and extension of technical and scientific investigation, research and experimentation by contributing the net earnings of the corporation, over and above such sum or sums as may be reserved or retained and held as an endowment fund or working capital, and also such other moneys and property belonging to the corporation as the Board of Directors shall from time to time deem 
proper, to the Smithsonian Institution, and such other scientific and educational institutions and societies as the Board of Directors may from time to time select in order to enable such institutions and societies to conduct such investigation, research and experimentation.

(c) To receive, hold and manage, and dispose of such other moneys and property, including the stock of this and of any other corporation, as may, from time to time, be given to or acquired by this corporation in the furtherance of its corporate purposes, and to apply the same and the proceeds or income thereof, to the objects specified in the preceding paragraph.

THIRD: The amount of the capital stock is Twenty thousand dollars $(\$ 20,000)$, and the amount of capital with which the corporation shall begin business is One thousand dollars $(\$ 1,000)$.

FOURTH: The number of shares of which the capital stock shall consist is Two hundred (200) of the par value of One hundred dollars ( $\$ 100)$ each. No dividends shall be declared or paid thereon, and the entire net profits earned by said capital stock shall be applied to or expended for the aforesaid purposes.

FIFTH : The principal office and place of business of the corporation is to be located in the Borough of Manhattan, City, County and State of New York, but it shall have power to carry on its work, and do business in any state, territory or dependency of the United States, or in the District of Columbia, or in any foreign country.

SixTH: The duration of the corporation shall be perpetual.

SEVENTH: The number of Directors of the corporation shall be fifteen, and they need not be stockholders. They shall have power to manage the affairs of the corporation, to make, amend and repeal such by-laws and regulations not inconsistent with the laws of this State or the United States, as they deem proper, and to appoint and employ such officers and employees as they consider necessary; and they may by by-laws or resolutions designate five or more Directors as an Executive Committee, with power to exercise all the rights 
and perform all the duties of the Board, which may be lawfully delegated in the management of the business of the corporation.

EIGHTH: The names and post-office addresses and places of residence of the Directors for the first year are :

NAMES.

William L. Dudley, T. Coleman du Pont, Frederick A. Goetze, Elon H. Hooker, Hennen Jennings, - W Washington, District of Columbia. Charles Kirchhoff, . 244 Riverside Drive, New York City. Benjamin B. Lawrence, I 7o West 59th Street, New York City. Arthur D. Little John B. Pine, Liloyd N. Scott, Charles A. Stone, James J. Storrow, Elihu Thomson, Charles D. Walcott, . Mark S. Reardon, 3rd,
P. O. ADDRESSES AND RESIDENCES.

Nashville, Tennessee. Wilmington, Deiaware. West I 7 th Street, New York City. 5 I 2 Fifth Avenue, New York City. Brookline, Massachusetts. - 24 Gramercy Park, New York City. I I East 44th Street, New York City. Plymouth, Massachusetts. Boston, Massachusetts. Swampscott, Massachusetts. I 70 Keap Street, Brooklyn, N. Y. Washington, District of Columbia.

NINTH: The said Directors shall, at their first meeting, classify themselves with respect to the time for which they shall severally hold office by dividing themselves into three classes, each consisting of one-third of the whole number of the Board of Directors. The Directors of the first class shall serve for a term of one year; the Directors of the second class for a term of two years; and the Directors of the third class for a term of three years; and at each annual election the successors to the class of Directors whose term shall expire in that year shall be elected to hold office for the term of three years, so that the term of office of one class of Directors shall expire in each year.

TENTH: The names and post-office addresses and places of residence of the subscribers and the number of shares which each agrees to take in the corporation are as follows:

NAMES,

ADDRESSES.

SHARES.

Frederick A. Goetze, 4I I West I I 7 th St., N. Y. City. Three. Elon H. Hooker, 512 Fifth Ave., N. Y. City. Four. Charles Kirchhoff, 244 Riverside, N. Y. City. Three. 
IN WITNESS WHEREOF, the undersigned have executed this certificate the I6th day of February, I9I2.

\section{FREDERICK A. GOETZE, ELON HUNTINGTON HOOKER, CHARLES KIRCHHOFF.}

$\left.\begin{array}{r}\text { STATE OF NEW YoRK, } \\ \text { County OF NEW YoRK, }\end{array}\right\}$ SS.:

On this I6th day of February, I912, before me personally came Frederick A. GOETZE, Elon Huntington Hooker and CHARLES KIRCHHOFF, to me known to be the individuals described in and who executed the foregoing Certificate of Incorporation, and severally acknowledged that they executed the same.

LLOYD N. SCOTT,
Notary Public,
(SEAL.) $\begin{aligned} & 3065 . \quad \text { New York County. } \\ & \text { County Clerk I ro. }\end{aligned}$

Filed in the office of the Secretary of State of the State of New York on the 26th day of February, I9I2, and in the office of the Clerk of the County of New York on the 27th day of February, I9I2. 


\section{BY-LAWS}

\section{ARTICLE I.}

\section{MEETINGS OF STOCKHOLDERS.}

SEC. I. The annual meeting of the stockholders of the Corporation shall be held on the third Friday of January in each year at the office of the Corporation, at two o'clock in the afternoon, or at such other hour and place in the State of New York as the Board of Directors may determine.

SEC. 2. At each annual meeting the stockholders shall elect five Directors to succeed the Directors whose terms have expired, or are about to expire, to serve for a term of three years, and such other Directors as may be necessary to fill vacancies in the Board of Directors caused by resignation or otherwise, for the unexpired terms.

SEC. 3. At least one month before each annual meeting the Secretary shall mail to each stockholder a list of the Directors, indicating those whose terms are about to expire and existing vacancies, with a request that nominations be submitted at least fifteen days before the date of the annual meeting.

SEC. 4. Notice of the time and place of annual meetings shall be given by publication thereof once in each week for two successive weeks immediately preceding such meeting in a newspaper published in the county where such meeting is to be held unless such publication shall be waived by all the stockholders, and in addition thereto a notice of the meeting either written or printed, or partly written or partly printed, shall be mailed or delivered ten days before such meeting to each stockholder, addressed to him at his post-office address appearing upon the books of the Corporation, unless such notice shall be waived. A list of nominations for Directors shall accompany every such notice. 
SEC. 5. Special meetings of the stockholders, except as otherwise required by statute, may be called at any time by the President, to be held at such time and place as the President may determine. It shail also be the duty of the President, or, in his absence, of the Vice-President, to call special meetings of the stockholders whenever requested in writing so to do by stockholders owning thirty per cent. of the outstanding capital stock ; and in case of a refusal or neglect to comply with such request, any three stockholders may call such meeting.

SEC. 6. Notice of special meetings shall be given by mailing or delivering a notice thereof to each stockholder, and addressed to him at his post-office address appearing upon the books of the Corporation, at least ten days before such meeting, unless such notice shall be waived. Such notice shall briefly state the object of said meeting, and no business not so stated shall be considered at such meeting, except on the unanimous consent of all stockholders present, in person or by proxy.

SHC. 7. At all stockholders' meetings, stockholders owning at least a majority of the outstanding capital stock of the Corporation, and present in person or by proxy, shall be necessary to constitute a quorum.

SEC. 8. If for any reason the annual meeting of stockholders shall not be held as hereinbefore provided, such annual meeting shall be called and conducted as prescribed by statute.

SEC. 9. At all meetings of stockholders, the following order of business shall be observed, so far as consistent with the purposes of the meeting, viz.:

Reading of Minutes.

Report of the Treasurer.

Report of the Secretary.

Report of Committees.

Election of Directors.

Miscellaneous Business.

SEC. IO. Every stockholder entitled to vote at any meeting may so vote by proxy provided that such proxy be executed in writing by the stockholder or by his duly authorized attorney. No proxy shall be valid after the expiration of eleven months from the date of its execution, unless the member executing it shall have specified therein the length of time it is to continue in force, which time shall not exceed five years. 
SEC. II. At all meetings of stockholders, all questions, unless otherwise provided by statute, shall be determined by a majority vote of the stockholders present in person or by proxy ; and in the event of a tie vote, the presiding officer of the meeting shall cast the deciding vote, provided that any person present may demand a stock vote, and when a stock vote is demanded, it shall immediately be taken, and each stockholder present, in person or by proxy shall be entitled to one vote for each share of stock he owns, as appears by the transfer book of the Corporation, and one vote for each share of stock so owned by any stockholder whose proxy he may be, and the question shall be decided affirmatively by a vote of not less than a majority of all outstanding shares of stock of said Corporation, except in the case of a sale, or mortgage of real estate, in which case an affirmative vote of not less than two-thirds of all outstanding stock shall be necessary.

SEC. 12. At all meetings for the election of Directors, two inspectors of election shall be first elected by a majority stock vote of all stockholders present at the meeting, in person or by proxy. Such Inspectors shall qualify as required by law.

\section{ARTICLE II.}

\section{BOARD OF DIRECTORS.}

SEC. I. The affairs of the Corporation shall be managed by a board of fifteen Directors, who shall be chosen only at the annual meeting of the stockholders, except as herein otherwise provided. The election of such Directors shall be held as provided by law.

SEC. 2. The Directors named in the certificate of incorporation shall at their first meeting divide themselves by lot into three classes, of five Directors in each class, to serve respectively for one, two and three years.

SEC. 3. In case of a vacancy by death, resignation or otherwise, in the Board of Directors between the time of the annual meetings, the remaining Directors shall fill the vacancy or vacancies by choosing as many persons as may be necessary to fill the same, and the person or persons so chosen shall be Directors and hold office until the next annual meeting of the stockholders, and until their successors are elected. 
SEC. 4. Any Director may be removed from his office for cause and after notice by an affirmative majority vote of the other Directors, and the remaining Directors shall, immediately after such vote, declare the office of such Director vacant, and the vacancy so created shall be filled in the same manner as any other vacancy.

SEC. 5. The annual meeting of the Board shall be held immediately after the annual meeting of the stockholders. Other meetings of the Board of Directors may be called by the President, or in his absence by the Vice-President, at any time on five days' notice, and it shall be his duty to call such meeting when so requested by two members of the Board. In case of his refusal or neglect to call a meeting when so requested, any three Directors may call such meeting. Seven Directors shall constitute a quorum at any meeting of the Board.

SEC. 6. The order of business at meetings of the Board shall be as follows :

I. Reading of the Minutes.

2. Report of the Treasurer.

3. Report of the Executive Committee.

4. Reports of Special Committees.

5. Unfinished business.

6. Miscellaneous business.

SEC. 7. No Director as such shall receive any salary or compensation for his services, but this shall not preclude him from holding any other office by appointment of the Board and receiving compensation therefor.

SEC. 8. The Board at its annual meeting shall elect a President, a Vice-President, a Secretary, a Treasurer and such other officers as they may deem necessary. One person may hold the offices of both Secretary and Treasurer.

SEC. 9. The Board shall from time to time appoint a manager and such other officers, agents and employees of the Corporation as they may deem necessary. Such officers, agents and employees shall respectively have such powers and perform such duties in the management of the property and affairs of the Corporation as usually pertain to their respective offices or as prescribed by the Board, subject always to the control 
of the Board ; and the Board may require any such officer, agent or employee to give security for the faithful performance of his duty, and may remove him at pleasure.

SEC. Io. The Board may adopt and from time to time amend, repeal, and add to such rules and regulations for the conduct of their meetings and the management of the affairs of the Corporation, as they may deem proper and which are not inconsistent with the law of the State of New York or of these by-laws.

\section{ARTICLE III.}

\section{OFFICERS.}

SEC. I. The officers of the Corporation shall be a President, a Vice-President, a Treasurer and a Secretary, who shall be elected by the Directors by ballot from the members of the Board, to serve for a term of one year. All vacancies occurring in such offices shall be filled by the Board for the unexpired term. The Board may also from time to time appoint a trust company to serve as Assistant Treasurer and to act as depositary of the funds of the Corporation, to hold office during the pleasure of the Board, with such powers as may be prescribed by the By-Laws or by resolution of the Board or of the Executive Committee.

SEC. 2. The President, or, in his absence, the VicePresident, shall preside at meetings of the stockholders and of the Board of Directors, and shall perform the usual duties of a presiding officer. The President or Vice-President shall sign all certificates of stock issued in the name of the Corporation.

SEC. 3. The Treasurer shall have general charge of the investment and safe-keeping of the property and funds of the Corporation, and of the disposition thereof, and shall see that all moneys and securities belonging to the Corporation are deposited with the Assistant Treasurer, and duly accounted for as provided for in the following section. It shall be the duty of the Treasurer to present a report of the receipts and expenditures of the preceding year, of the funds and assets of the Corporation, and of the manner in which the funds are invested at the annual meeting and at such other times as the Executive Committee may direct. 
SEC 4. The Assistant Treasurer shall be a trust company and shall be charged with the following powers and duties under the direction of the T'reasurer:

(a) The custody and safe keeping of money and securities belonging to the Corporation, and the collection of income and other moneys due to the Corporation, with power to receipt for the same, and to endorse for deposit all checks payable to the order of the Corporation or the Treasurer.

(b) The investment and reinvestment of capital under the direction of the Executive Committee.

(c) The disbursements of the funds of the Corporation under the direction of the Board of Directors or of the Executive Committee, and such disbursements shall be made either pursuant to resolutions adopted by the Board or by the Executive Committee and filed with the Assistant Treasurer, or upon the written approval of the Treasurer or Secretary, and a member of the Executive Committee.

(d) The keeping of proper books of account and rendering statements of receipts and disbursements together with trial balances and such further accountings or statements as may from time to time be called for by the Treasurer or the Executive Committee.

(e) Such other duties as may be specifically assigned by the Board or the Executive Committee.

SEC. 5. The Secretary shall keep a stock book, a subscription list book showing the names of the stockholders and the amount of capital remaining to be paid upon their respective subscriptions, and shall also keep a membership book in which shall be entered the names and postoffice addresses of the stockholders of the Corporation. The Secretary shall also be the transfer agent of the Corporation for the transfer of all certificates of stock, and shall sign all such certificates. He shall also keep the seal of the Corporation and affix the same to all certificates of stock and such other instruments requiring its seal as may be directed by the Board of Directors or the Executive Committee. The Secretary shall also keep the minute book of meetings of the stockholders and Directors issue notices of meetings, and perform such other duties as may be required by the Board of Directors. 


\section{ARTICLE IV.}

\section{CommitTeEs.}

SEC. I. At the annual meeting of the Board, or as soon thereafter as possible there shall be elected five Directors to constitute an Executive Committee for the ensuing year. Three members of such Committee shall constitute a quorum at its meetings.

SEC. 2. The Committee shall have the charge and management of the affairs and business of the Corporation, and during the intervals between the meetings of the Board shall have and exercise all the powers of the Board incident thereto.

SEC. 3. The Committee shall keep minutes of its meetings and submit the same at each meeting of the Board.

SEC. 4. At least two weeks before the annual meeting the President, or in his absence the Vice-President, shall appoint a committee of two Directors to audit the accounts of the Corporation and to report at the next succeeding annual stockholders' meeting. Such Committee shall have power to employ a certified public accountant to make such audit.

\section{ARTICLE V.}

STOCK.

SEC. I. Certificates of stock of the Corporation shall not be transferred, sold, assigned or pledged except subject to such limitations and restrictions as may be agreed upon by the stockholders and the corporation, provided, however, that when so authorized such transfer, sale, assignment or pledge shall be made by an endorsement to the proper effect in writing on the back of the certificate, and delivery of such certificate by the transferrer to the transferee, and payment of the transfer tax; but until notice given of such transfer to the Secretary of the Corporation, and the surrender of the outstanding certificate of stock for cancellation, and the payment of the transfer tax, and the issue of a new certificate in lien of that surrendered, the Corporation may regard and treat the transferrer as being still the owner of the stock.

SEC. 2. All such surrendered certificates shall be marked cancelled, with the date of cancellation, by the Secretary, and each shall be immediately pasted into the stock certificate book opposite the entry of its issue. 
SEC. 3. The corporation shall not purchase its own stock except from its surplus earnings unless such purchase is made for the purpose of the immediate sale and reissue thereof, and no such purchase shall be made if the capital of the Corporation will be thereby impaired.

\section{ARTICLE VI.}

\section{MisceilaneOUS.}

SEC. I. The fiscal year of the Corporation shall begin on January $I$ and terminate on December $3 \mathrm{I}$.

SEc. 2. No debts shall be contracted or liability incurred or contract made and entered into by and in behalf of this Corporation by any officer or agent thereof unless the same be authorized and directed by the Board of Directors or the Executive Committee.

SEC. 3. The seal of the Corporation shall be in the form of a circle, containing the inscription, Research Corporation, New York, surrounding the inscription, Corporate Seal IgI2.

SEC. 4. These By-Laws may be amended at any meeting of the stockholders or of the Board of Directors, as the case may be, by unanimous vote, or, by a two-thirds vote when fifteen days' previous notice of the proposed amendment has been mailed or delivered to each stockholder or Director, provided that no amendment adopted by the Board of Directors. regulating the election of Directors or officers shall be valid unless published as required by law. A copy of any amendment to the by-laws shall be sent to each stockholder and each Director within ten days after its adoption. 


\section{STOCKHOLDERS AGREEMENT}

This AGREement, made this 27th day of February, I912, between FREDERICK A. GOETZE, ELON HunTINGTON HoOKeR, Charles KIRCHHOFF, and such other persons as may hereafter become parties to this agreement (hereinafter referred to as "the Stockholders"), of the first part, and the "RESEARCH CORPORATION", a corporation organized under the laws of the State of New York (hereinafter referred to as "the Corporation"), of the second part.

WHEREAS, the said corporation has been organized for the purpose of aiding. and encouraging technical and scientific research, as provided in its Certificate of Incorporation, and not for personal or individual profit; and

WHEREAS, the said stockholders are the owners of all the capital stock of said corporation which has been issued or subscribed for, and are desirous that the profits, if any, accruing from the business of said corporation shall be devoted exclusively to the aforesaid purposes and to no other ;

WITNESSETH : That the said stockholders, each for himself, in consideration of the sum of One Dollar, by each to the other in hand paid, and of a like amount paid by the said corporation, and the covenants and agreements herein contained, do hereby mutually agree to and with each other and with said corporation :

First.-That they, the said stockholders, will not, nor will any of them sell, assign, or otherwise dispose of or transfer any or all of said stock so held by them respectively, or any part thereof, unless and until the stockholder intending to sell, assign, or otherwise dispose of or transfer his stock shall first have given notice in writing to the corporation, through its Treasurer, of such intention.

Second.-That upon receiving such notice the corporation shall have the right and option at any time within ninety (9o) days thereafter to purchase such stock at par (or for so much of the par value as shall have been actually paid thereon), provided, however, that if the corporation shall not exercise such 
option within the time limited the owner of the stock shall be entitled to the possession of the certificate representing such stock and shall have the unrestricted right to dispose of the same, notwithstanding this agreement.

Third. - That in the event of the death of a stockholder, the corporation shall have the right and option at any time within ninety (90) days after letters testamentary have been granted on his estate, to purchase the stock of this corporation owned by such stockholder at par (or for so much of the par value as shall have been actually paid thereon), provided, however, that if the corporation shall not exercise such option within the time limited the owner of the stock, or his personal representative, shall have all the rights reserved by the preceding paragraph.

Fourth.-That the said corporation shall have the right and option at any time (subject to the provisions of paragraphs second and third) to purchase any of the stock of this corporation now or hereafter owned by said stockholders at par (or for so much of the par value as shall have been actually paid therefor).

Fifth. - That no stock purchased by the corporation under the foregoing provisions shall be transferred to any person unless and until he shall assent to the terms of this agreement and become a party thereto by accepting such transfer subject to the terms hereof; that no stock now in the treasury shall be issued except under and subject to the foregoing provisions, and that it shall be stated upon the face of each certificate of stock now or hereafter issued by the corporation that the same is issued, held and owned subject to the terms of this agreement, reserving, however, to the respective owners for the time being of the stock heretofore or hereafter issued the right to vote thereon at all meetings of stockholders of the corporation and all other rights properly belonging to them as stockholders.

Sixth.-That in furtherance of the purposes of this agreement, and for the better carrying out of the same, the stockholders shall endorse in blank the several certificates of stock owned by or issued to them respectively, and that all purchasers of stock hereafter sold by the corporation shall as a condition of such purchase be required to do the same, and shall 
deposit such stock in escrow with the Treasurer for the time being of said corporation, to be held by him and his successors for delivery to the person or corporation entitled thereto when so required by the terms of this agreement.

AND WE, the said stockholders, do hereby severally nominate, constitute and appoint the Treasurer for the time being of said corporation our true and lawful attorney irrevocable, for us and each of us respectively, and in our respective names, to transfer and deliver the stock certificates so deposited, when so required by the terms of this agreement.

This agreement shall apply to and bind the parties hereto and their respective executors, administrators, successors and assigns.

IN WITNESS WHEREOF, the said stockholders have hereunto set their hands and seals, and the said corporation has caused these presents to be executed the day and year first above written.

FREDERICK A. GOETZE, ELON HUNTINGTON HOOKER, CHARLES KIRCHHOFF,

RESEARCH CORPORATION, By

LLOYD N. SCOTT,

Secretary.

IN THE PRESENCE OF :

F. G. COTTRELI.

$\left[\begin{array}{c}\text { CORPORATE } \\ \text { SEAL }\end{array}\right]$ 






and 



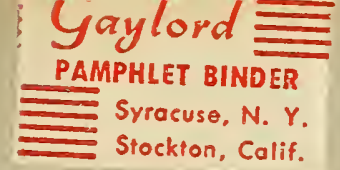




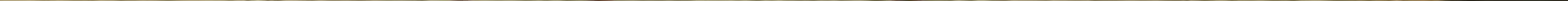

